\title{
COMPARATIVE FLORAL SURFACE MICROMORPHOLOGY HELPS TO DISCRIMINATE BETWEEN SPECIES OF PAPHIOPEDILUM (ORCHIDACEAE: CYPRIPEDIOIDEAE) FROM PENINSULAR MALAYSIA
}

\author{
Edward E. Besi, Lam S. Jia, Muskhazli Mustafa, Christina S.Y. Yong \\ \& RUSEA Go*
}

Department of Biology, Faculty of Science, Universiti Putra Malaysia, 43400 Serdang, Selangor Darul Ehsan, Malaysia

*Author for correspondence: rusea@upm.edu.my

\begin{abstract}
The floral micromorphology of critically endangered Paphiopedilum Pfitzer [P. barbatum (Lindl.) Pfitzer, $P$. callosum var. sublaeve (Rchb.f.) P.J.Cribb and $P$. niveum (Rchb.f.) Stein] were analyzed concerning either infrageneric taxonomy or physioecological demands. The first two species are phylogenetically close and superficially identical but occur with distinct phytogeographical distributions in the region. The third species is a phylogenetically distant congener that inhabits limestone areas in the northern part of Peninsular Malaysia. Using scanning electron microscopy (SEM), we investigated the surface of the dorsal sepal, synsepal, lateral petals, pouch or labellum, and staminode. Amongst the investigated features were epicuticular waxes, epicuticular ornamentation, trichome distribution and type, pustular glands, and papillae. Our study supports the distinction of $P$. barbatum from $P$. callosum var. sublaeve, which belong to subgenus Paphiopedilum, and from P. niveum, a species belonging to subgenus Brachypetalum, a separated monophyletic clade. Comparatively, $P$. barbatum has Type III non-glandular trichomes on the margin of its lateral petals, which are absent in P. callosum var. sublaeve. Paphiopedilum callosum var. sublaeve and $P$. niveum are distinguishable from $P$. barbatum by a confined distribution of papillae. The epicuticular ornamentation and distribution of trichomes on staminode discriminate between $P$. barbatum and $P$. callosum var. sublaeve and differentiates them from $P$. niveum. Compared to $P$. barbatum and $P$. niveum, stomata in $P$. callosum var. sublaeve were superficial with prominently raised guard cells. From the physioecological view, the absence of glandular trichomes, and the low occurrence of papillae and stomata on the floral parts explain the unscented flowers of $P$. barbatum and $P$. callosum var. sublaeve. A combination of the features examined is taxonomically valuable for delimitation of the species at the infrageneric level, although the diagnostic characters are far inadequate for a generic taxonomic revision. A study with a more extensive sampling from the three subgenera of Paphiopedilum, including subgenus Parvisepalum, is anticipated to elucidate the level of variation of the analyzed microcharacters.
\end{abstract}

Key Words: physioecological importance, Peninsular Malaysia, subgenus Brachypetalum, subgenus Paphiopedilum, scanning electron microscopy, taxonomic delimitation

Introduction. Paphiopedilum originates from the Greek word 'Paphian' an epithet for Aphrodite, the Roman goddess known as Venus, and "pedilon" which means slipper (Cash 1991, Cribb 1998). Orchids in this genus are commonly known as slipper orchids because of the unique slipper or shoe-like flowers (Cash 1991, Cribb 1998, McGough et al. 2006). The genus Paphiopedilum Pfitzer comprises about 167 species, with distribution extending from Southern China to Tropical Asia (Braem 1988, Cribb 1998, Chen et al. 2005, Govaerts et al. 2021). Paphiopedilum gained its popularity and investment value in the horticulture industry through its exotic appearance and production of large flowers on small plants (Cribb 1998). Most of the species are regarded as endangered and threatened with extinction due to habitat destruction, overcollection and illegal trading. They are amongst the plants listed on the Convention on International Trade in Endangered Species of Wild Fauna and Flora (CITES Appendix 1). Within this list, one can find well-known Malaysian species Paphiopedilum barbatum (Lindl.) Pfitzer (Bearded Paphiopedilum) (Rankou 2015a), 
Paphiopedilum callosum (Rchb.f.) Stein (Callus Paphiopedilum) (Rankou et al. 2015), Paphiopedilum niveum (Rchb.f.) Stein (Snow-White Paphiopedilum) (Rankou 2015b), Paphiopedilum rothschildianum (Rchb.f.) Stein (Rothschild's Paphiopedilum) (Rankou 2015c), Paphiopedilum sanderianum (Rchb.f.) Stein (Sander's Paphiopedilum) (Rankou 2015d) and Paphiopedilum stonei (Rchb.f.) Stein (Rchb.f.) Stein (Stone's Paphiopedilum) (Rankou \& O'Sullivan 2015).

Systematically, Paphiopedilum is considered an early branch group due to its geographical distribution and relatively unspecialized floral structures (Rosso 1966). The subfamily Cypripedioideae is unusual amongst the Orchidaceae because of the presence of two fertile stamens, the disposition of these stamens in the inner staminal whorl lateral to the style, and the incomplete adnation of stylar and staminal tissues (Rosso 1966). A saccate labellum is usually present and is responsible for the common name "slipper orchids" so often applied to these plants (Seidenfaden \& Wood 1992, Cribb 1998). Taxonomically, Paphiopedilum is classified based on morphological, cytological, and molecular phylogenetic data into three subgenera; Parvisepalum, Brachypetalum and Paphiopedilum (Cribb 1998, Chochai et al. 2012). Until now, only subgenus Brachypetalum and subgenus Paphiopedilum are recorded for Peninsular Malaysia. We investigate four aspects to identify an orchid species: general morphology, chromosome numbers, leaf and floral anatomy, and DNA barcoding. Species delimitation based on general floral morphology for Paphiopedilum species found in Peninsular Malaysia shows a clear resolution for most of the species, except for the highly resemblant ones, for instance, $P$. barbatum and P. callosum var. sublaeve (Rchb.f.) P.J.Cribb belong to subgenus Paphiopedilum (Seidenfeiden \& Wood 1992, Cribb 1998, Leong 2014). A work on DNA Barcoding of Endangered Paphiopedilum species of Peninsular Malaysia using four DNA barcode loci and their combinations ( $r b c L$, matK, ITS, trnH-psbA) published by Rajaram et al. (2019) clusters each species as a monophyletic clade. The matK sequences discriminate the closely related $P$. barbatum and $P$. callosum var. sublaeve, therefore supporting the species circumscription by Cribb (1998) (Rajaram et al. 2019). Nevertheless, slipper orchids are infamously variable, and unusual plants may sometimes be natural hybrids, especially when the putative parents grow sympatrically (Averyanov et al. 2007, Leong 2014, van der Ent et al. 2015). Natural hybridizations between two confusable Paphiopedilum species occur in Peninsular Malaysia, e.g. in between P. barbatum and $P$. callosum var. sublaeve - where the chloroplast matK $K$ sequence matched that of $P$. barbatum and the nuclear ITS sequence matched that of $P$. callosum var. sublaeve (Khew in prep. cited in Leong 2014).

Cytologically, the genus is characterized by significant chromosome variation, ranging from $2 n=26$ to 42 (Duncan \& Macleod 1949, Karasawa 1979, Karasawa \& Aoyama 1988). Pollen studies and anatomy observations on the leaf, root, stem, and inflorescence for members of subfamily Cypripediodeae are enumerated in Pfitzer (1903), Holm (1904), Cheadle (1942), Rosso (1966) and Atwood (1984). The systematic significance of inner and outer cuticular micromorphology of mottled and xeromorphic leaves of Paphiopedilum species is unclear for either taxonomical or ecological purposes (Guan et al. 2011). The floral micromorphology of this genus, on the other hand, has not been thoroughly examined, except for pollen morphology. Pollens of some Paphiopedilum species, including P. barbatum, $P$. callosum and $P$. niveum, were studied under the microscope by Williams \& Broome (1976), Newton \& Williams (1978), and Burns-Balogh \& Hesse (1988), are taxonomically useful at the intergeneric level. The exine of P. callosum is formed by isolated sporopollenin particles of the thick, peripherally channelled intine. Paphiopedilum niveum differs by having the foveolate exine with small pits. However, studies on the micromorphology of other floral parts of the genus Paphiopedilum are lacking. Given the above, we employed scanning electron microscope (SEM) observations to evaluate surface microstructures' applicability in taxonomic delimitation and physioecological functions.

\section{Materials and methods}

Species selection.- Three Paphiopedilum species from Peninsular Malaysia were selected to predict the congeneric contrasts (Fig.1): Paphiopedilum barbatum and $P$. callosum var. sublaeve belong to section Barbata in subgenus Paphiopedilum with mottled 


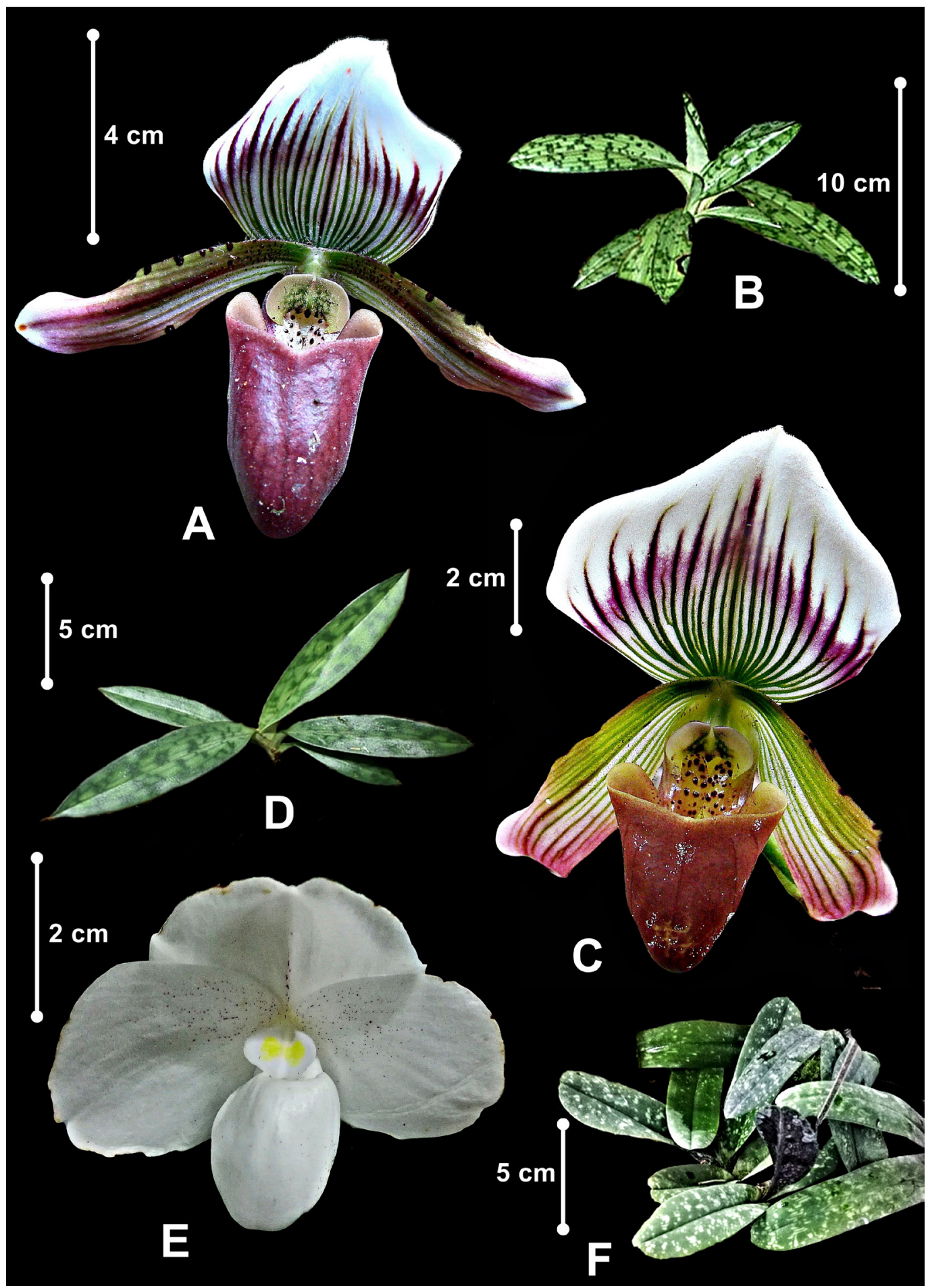

Figure 1. Examined species of Paphiopedilum from Peninsular Malaysia. A-B. Paphiopedilum barbatum flower (A) and leaves (B). C-D. Paphiopedilum callosum var. sublaeve flower (C) and leaves (D). E-F. Paphiopedilum niveum flower (E) and leaves (F). Photographs by Rusea Go and Edward Entalai Besi. 
TABle 1. Paphiopedilum species examined including their locality, habitat and voucher.

\begin{tabular}{lccc}
\hline Species & $\begin{array}{c}\text { Type } \\
\text { Locality }\end{array}$ & Habitat & $\begin{array}{c}\text { Voucher } \\
\text { Deposited }\end{array}$ \\
\hline P. barbatum & Terengganu & $\begin{array}{c}\text { Peaty areas and } \\
\text { rocky boulder in } \\
\text { waterfall in lower } \\
\text { montane forest }\end{array}$ & $\begin{array}{c}\text { EDW060 } \\
\text { (UPM) }\end{array}$ \\
\hline $\begin{array}{c}\text { Highland heath } \\
\text { P. callosum } \\
\text { vablaeve }\end{array}$ & Kedah & $\begin{array}{c}\text { Horest with ground } \\
\text { made up of granite, } \\
\text { quartzite and } \\
\text { sandstone }\end{array}$ & $\begin{array}{c}\text { RG4574 } \\
\text { (UPM) }\end{array}$ \\
\hline P. niveum & Perlis & Limestone hill forest & WY125 \\
(UPM)
\end{tabular}

leaves, mostly spotted warty petals and thick-textured labellum, and $P$. niveum, the only representative of subgenus Brachypetalum in Peninsular Malaysia, with mottled leaves, concolourous white flowers and thin-textured labellum. Paphiopedilum barbatum thrives under deep dark valleys, open areas or rocky boulders covered with humus, leaf litters or carpets of thick moss at streamside from about $200 \mathrm{~m}$ to 1200 $\mathrm{m}$ a.s.1. Both $P$. callosum var. sublaeve and $P$. niveum confined to the northern part of Peninsular Malaysia differ in habitat types. Paphiopedilum callosum var. sublaeve occurs in mossy forest or open vegetation with the ground covered with sphagnum mosses or coarse white sand, whereas, $P$. niveum is a calcicoles congener inhabiting limestone cliff shaded from direct sunlight at about $300 \mathrm{~m}$ a.s.l.

Sample collection and processing.- - One individual for each species was obtained through field sampling conducted in three different localities in Peninsular Malaysia, allowed by a permit. A complete specimen for each species was processed as an herbarium specimen following techniques outlined in Bridson \& Forman (2000) and deposited in the Herbarium of Universiti Putra Malaysia (UPM). The voucher numbers and attributes are listed in Table 1. Two flowers of each species were used in macro- and micromorphology examinations. The flower specimens were dissected and photographed under AM4113ZT Dino-Lite Digital Microscope. Species identification was accomplished by morphological assessment by referring to the published taxonomic monographs and the botanical illustrations of Seidenfaden \& Wood (1992) and Leong
(2014). The currently accepted names of the orchids were validated through the KEW World Checklist of Selected Plant Families (Govaerts et al. 2021).

Micromorphology examination.- The microstructural study was carried out in Microscopy Unit (EM) in the Institute of Biological Sciences (IBS), UPM, Malaysia. The floral parts examined were dorsal sepal, synsepal, lateral petals, pouch or labellum and staminode. For SEM, the samples were processed according to a modified protocol by IBS explained in Besi et al. (2020): First, fragments about $1 \mathrm{~cm} \times 1 \mathrm{~cm}$ were excised from the margin, basal, apex and middle portions of the floral parts, except for the staminode which was used entirely. The excised samples were put into separate vials and soaked in fixative (4\% glutaraldehyde) for two days at $4 \mathrm{oC}$. After two days, samples were washed with $0.1 \mathrm{M}$ sodium cacodylate buffer for three changes of $30 \mathrm{~min}$ each and postfixed in $1 \%$ osmium tetraoxide for $2 \mathrm{~h}$ at $4 \mathrm{oC}$. Then, samples were rewashed with $0.1 \mathrm{M}$ sodium cacodylate buffer (three times $30 \mathrm{~min}$ each) before dehydration with series of acetone: $35 \%$ (30-45 $\mathrm{min}$ ), $50 \%$ (30-45 $\mathrm{min}$ ), $75 \%$ (30-45 $\mathrm{min}$ ), $95 \%$ (30-45 $\mathrm{min}$ ), and $100 \%$ ( $1 \mathrm{~h}$ for three changes). The samples were further dried using the critical dryer Leica EM CPD 030 for about $30 \mathrm{~min}$. Lastly, the samples were mounted on stubs using double-sided carbon adhesive tabs and then sputter-coated with gold in auto fine coater Baltec SCD 005 Sputter Coater. The coated samples were examined under the Jeol JSM 6400 SEM (Beam voltage: $15 \mathrm{kV})$. The surface of each floral part was observed under various magnifications $(15 \mathrm{x}-4000 \mathrm{x})$. All the stubs prepared are housed in the EM unit in IBS, UPM, Malaysia.

The microstructures observed on the floral parts were trichomes and papillae, pustular glands, stomata, epicuticular ornamentation and waxes. Classification of stomata was according to Wilkinson (1979) and Carpenter (2005) based on shapes and patterns of the stomatal ledges flanking aperture, guard cells and peristomatal striae, and arrangement of the contact cells. Here, we have adopted the term 'contact cell' to take the place of the subsidiary cell and neighbouring cell, to refer to any cell, specialized or not, that is adjacent to the stoma (Upchurch 1984). The studied Paphiopedilum species have some stomata where 
TABle 2. Trichomes types on the floral parts Paphiopedilum barbatum, $P$. callosum var. sublaeve and $P$. niveum, including description on the morphology.

\begin{tabular}{cl}
\hline Type & \multicolumn{1}{c}{ Morphology description } \\
\hline I & $\begin{array}{l}\text { Simple, uniseriate, non-glandular, unicellular, rugose, } \\
\text { ca. 100-200 } \mu \mathrm{m} \text {, narrowly clavate }\end{array}$ \\
\hline II $\quad \begin{array}{l}\text { Simple, uniseriate, non-glandular, multicellular, long, ca. } \\
200-1,000 \mu \mathrm{m}, \text { moniliform }\end{array}$ \\
\hline III $\quad \begin{array}{l}\text { Simple, uniseriate, non-glandular, multicellular, } \\
\text { elongated, ca. 200-2,000 } \mu \mathrm{m}, \text { moniliform with topmost } \\
\text { cell very narrow }\end{array}$ \\
\hline IV $\quad \begin{array}{l}\text { Simple, multiseriate, non-glandular, bicellular, } \\
\text { multiseriate base, short, ca. 100-400 } \mu \mathrm{m}\end{array}$ \\
\hline V $\quad \begin{array}{l}\text { Simple, uniseriate, non-glandular, bicellular or } \\
\text { multicellular, short, ca. 100-400 } \mu \mathrm{m}\end{array}$ \\
VI $\quad \begin{array}{l}\text { Simple, uniseriate, glandular, unicellular, sessile, ca. } \\
\text { 5-20 } \mu \mathrm{m}, \text { barrel-shaped }\end{array}$ \\
\hline
\end{tabular}

contact cells' patterns were not shown clearly in the SEM micrographs. Thus, the stomata type was omitted from the analysis and these stomata were described based on guard cells, stomatal ledges and peristomatal striae. For the individual stomatal parameters, stoma length and width, a magnification of $500 \mathrm{x}$ and a measurement method in Savvides et al. (2011) were employed in the current study. Stoma width was chosen instead of guard cell width since the latter changes up to $50 \%$ as stomata close (Shope \& Mott 2006). Meanwhile, trichomes were described and classified based on Theobald et al. (1979), Adedeji et al. (2007), and Angulo \& Dematteis (2014). Comprehensive terminologies of trichome morphology follow Angulo \& Dematteis (2014). The parameter measurements were done using a ruler and the values obtained were multiplied with the magnification scales. Surface's cuticular ornamentation was described following Piwowarczyk (2015), Ghimire et al. (2018), and Kong \& Hong (2018), and description on epicuticular waxes was based on Wilkinson (1979). Assessment of the examined species and the comparative study were conducted following Ghazalli et al. (2019).

Results. Epicuticular ornamentation was observed on the floral parts of the selected Paphiopedilum species. Six different features of simple and uniseriate trichomes, vary in structure, distribution, and number of cells, except branched trichomes. Description of the epicuticular ornamentation and trichomes are in Tables 2 and 3.
TABLE 3. Epicuticular ornamentation on the floral parts Paphiopedilum barbatum, P. callosum var. sublaeve and $P$. niveum, including description on the morphology.

\begin{tabular}{cl}
\hline Type & \multicolumn{1}{c}{ Morphology description } \\
\hline I & $\begin{array}{l}\text { Foveate outer periclinal wall; furrowed, straight and } \\
\text { rounded anticlinal wall }\end{array}$ \\
\hline II & $\begin{array}{l}\text { Foveate outer periclinal wall; fibrillary, straight and } \\
\text { rounded anticlinal wall }\end{array}$ \\
\hline III & $\begin{array}{l}\text { Flat outer periclinal wall; reticulate, fibrillary, straight and } \\
\text { rounded anticlinal wall }\end{array}$ \\
\hline IV & $\begin{array}{l}\text { Laevigate and often striated outer periclinal wall; } \\
\text { undulate and furrowed anticlinal wall }\end{array}$ \\
\hline V & $\begin{array}{l}\text { Outer periclinal wall with a complex network of undulate } \\
\text { striae; fibrillary, straight and rounded anticlinal wall }\end{array}$ \\
\hline VI & $\begin{array}{l}\text { Entirely covered by hairs (Type I non-glandular } \\
\text { trichomes) }\end{array}$ \\
\hline VII & $\begin{array}{l}\text { Laevigate-with-seams outer periclinal wall; furrowed, } \\
\text { straight and rounded anticlinal wall }\end{array}$ \\
\hline
\end{tabular}

Species assessment under SEM. - Paphiopedilum barbatum (Fig. 2). Waxes: scattered, wartygranulated and flake-like. Epicuticular ornamentation: Type III, IV and VII. Stomata formation: same level with the epidermal wall, in parallel or random formation. Stomata distribution: sparsely occurred on dorsal sepal, synsepal, lateral petals, labellum and staminode. Stomata ornamentation: comprise a defined rosette of five to seven contact cells with radial elongation of some cells but not others or characterized by four lateral contact cells. Guard cells and ledges indistinguishable from the neighbouring stomatal apparatus in the staminode. Stomatal cuticular striation: smooth or slightly striated. Stomatal size: L (11.11-41.67 $\mu \mathrm{m}) \times \mathrm{W}(4.44-33.33 \mu \mathrm{m})$. Trichome distribution: present on dorsal sepal, synsepal, lateral petals, labellum and staminode. Trichome type: non-glandular-Type I, II, III, and V; glandular-absent. Pustular glands: absent. Papillae: absent.

Paphiopedilum callosum var. sublaeve (Fig. 3). Waxes: scattered, warty-granulated and flake-like. Epicuticular ornamentation: Type II, III, IV, VI, and VII. Stomata formation: superficial, raised from the epidermal wall. Stomata distribution: sparsely occurred on dorsal sepal, synsepal and lateral petals. Stomata ornamentation: narrowly elliptical outer stomatal ledges with prominent guard 


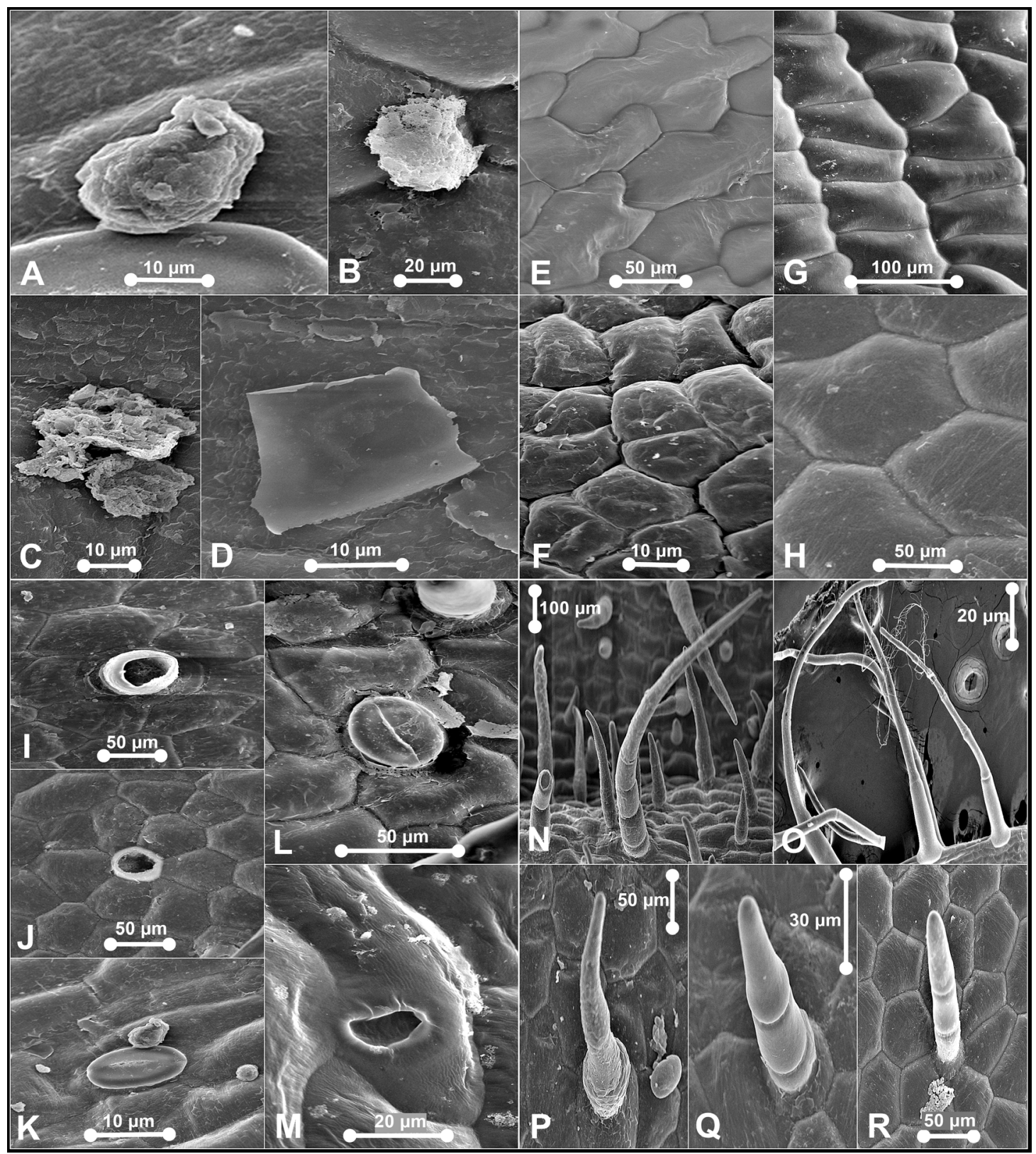

FIGURE 2. SEM observations of epicuticular waxes (A-D), epicuticular ornamentation (E-H), stomata (I-M) and trichomes (N-R) on floral parts of Paphiopedilum barbatum. A. Warty-granulated wax. B. Warty-granulated wax. C. Wartygranulated wax. D. Flake-like wax. E. Type III epicuticular ornamentation. F. Type IV epicuticular ornamentation. G. Type VII epicuticular ornamentation. H. Type VII epicuticular ornamentation. I. Aperture from by detachment of trichome on dorsal sepal. J. Aperture from by detachment of trichome on synsepal. K. Stoma on synsepal characterized by four lateral contact cells. L. Stoma on synsepal - comprise a defined rosette of five to six contact cells. M. Nectarostoma on staminode. N. Trichomes on dorsal sepal - Type II. O. Trichomes on petal - Type II. P. Trichomes on dorsal sepal and staminode - Type II. Q. Trichomes on labellum - Type II. R. Trichomes on petal and labellum Type II. Photographs by Edward Entalai Besi. 


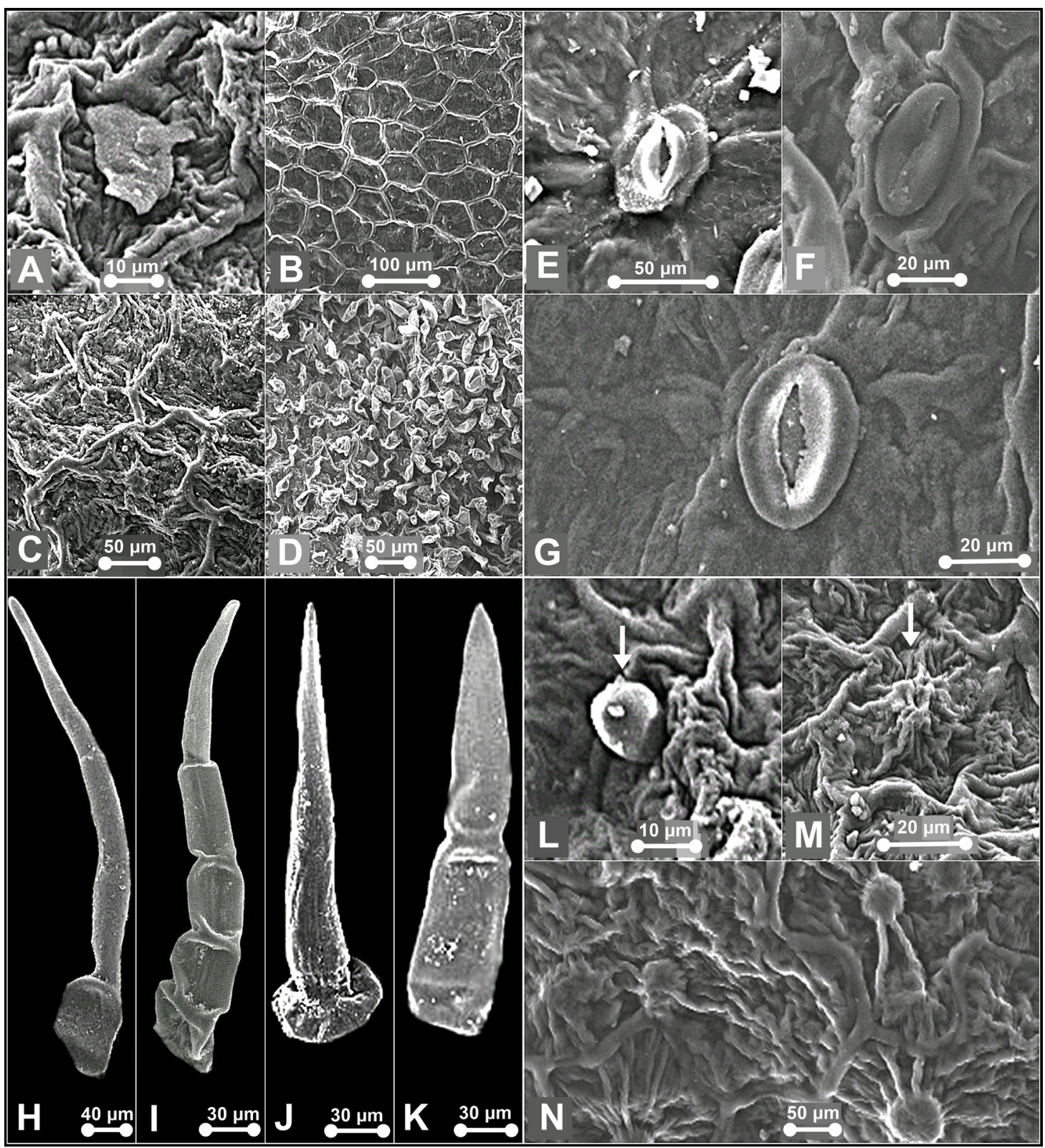

Figure 3. SEM observations of epicuticular waxes (A), epicuticular ornamentation (B-D), stomata (E-G), trichomes (HL) and papillae (M-N) of Paphiopedilum callosum var. sublaeve and P. niveum. A. Flake-like wax on the pouch of $P$. niveum. B. Type II epicuticular ornamentation. C. Type V epicuticular ornamentation. D. Type VI epicuticular ornamentation. E. Stoma on dorsal sepal of $P$. callosum var. sublaeve. F. Stoma on lateral sepals of $P$. niveum. G. Stoma on dorsal sepal of $P$. niveum. H. Trichomes on synsepal of $P$. callosum var. sublaeve. I. Trichome on dorsal sepal of $P$. callosum var. sublaeve. J. Trichome on dorsal sepal of $P$. niveum - Type IV. K. Trichome on synsepal of $P$. callosum var. sublaeve - Type IV. L. Trichome on the pouch of $P$. niveum - Type VII. M. Papillae on the pouch of $P$. niveum tall and striated. N. papillae on the pouch of P. callosum var. sublaeve - globular and striated. Photographs by Edward Entalai Besi and Lam Shun Jia. 
TABle 4. Features and distribution of floral-surface micromorphology characteristics of Paphiopedilum barbatum, P. callosum var. sublaeve and $P$. niveum (epidermal, stomata).

\begin{tabular}{|c|c|c|c|c|c|c|c|}
\hline Species & Floral parts & $\begin{array}{l}\text { Epicuticular } \\
\text { ornamentation }\end{array}$ & $\begin{array}{c}\text { Anticlinal } \\
\text { wall features }\end{array}$ & $\begin{array}{l}\text { Epicuticular } \\
\text { striation }\end{array}$ & $\begin{array}{c}\text { Stomata } \\
\text { contact and } \\
\text { epidermal cells } \\
\text { ornamentation }\end{array}$ & $\begin{array}{c}\text { Peristomatal } \\
\text { rim } \\
\text { ornamentation }\end{array}$ & $\begin{array}{c}\text { Pattern of } \\
\text { stomatal } \\
\text { distribution }\end{array}$ \\
\hline \multirow{5}{*}{ P. barbatum } & $\begin{array}{l}\text { Dorsal } \\
\text { Sepal }\end{array}$ & III, IV & Furrowed & Smooth & Present & Present & Parallel \\
\hline & Synsepal & III, VII & Furrowed & Smooth & Present & Present & Random \\
\hline & $\begin{array}{c}\text { Lateral } \\
\text { Petals }\end{array}$ & IV, VII & $\begin{array}{l}\text { Fibrillary, } \\
\text { furrowed }\end{array}$ & Smooth & Present & Present & Random \\
\hline & Labellum & IV & $\begin{array}{l}\text { Undulate, } \\
\text { furrowed }\end{array}$ & Smooth & Present & Present & Parallel \\
\hline & Staminode & VII & Furrowed & Smooth & Present & Present & Parallel \\
\hline \multirow{5}{*}{$\begin{array}{l}\text { P. callosum } \\
\text { var. sublaeve }\end{array}$} & $\begin{array}{l}\text { Dorsal } \\
\text { Sepal }\end{array}$ & II & Fibrillary & Rugulate & Present & Present & Parallel \\
\hline & Synsepal & II, VII & $\begin{array}{l}\text { Fibrillary, } \\
\text { furrowed }\end{array}$ & Rugulate & Present & Present & Parallel \\
\hline & $\begin{array}{c}\text { Lateral } \\
\text { Petals }\end{array}$ & II, III & Fibrillary & Rugulate & Present & Present & Parallel \\
\hline & Labellum & IV & $\begin{array}{l}\text { Undulate, } \\
\text { furrowed }\end{array}$ & $\begin{array}{l}\text { Rugulate, } \\
\text { striated }\end{array}$ & Absent & Absent & Absent \\
\hline & Staminode & VI & Unclear & Unclear & Absent & Absent & Absent \\
\hline \multirow{5}{*}{$P$. niveum } & $\begin{array}{l}\text { Dorsal } \\
\text { Sepal }\end{array}$ & III & Fibrillary & $\begin{array}{l}\text { Densely } \\
\text { rugulate }\end{array}$ & Present & Present & Parallel \\
\hline & Synsepal & III & Fibrillary & Striated & Present & Present & Parallel \\
\hline & $\begin{array}{c}\text { Lateral } \\
\text { Petals }\end{array}$ & II & Fibrillary & $\begin{array}{l}\text { Rugulate, } \\
\text { striated }\end{array}$ & Absent & Absent & Absent \\
\hline & Labellum & II, V & Fibrillary & $\begin{array}{l}\text { Rugulate, } \\
\text { striated }\end{array}$ & Absent & Absent & Absent \\
\hline & Staminode & VI & Unclear & Unclear & Absent & Absent & Absent \\
\hline
\end{tabular}

cells. Contact cells indistinguishable. Stomatal cuticular striation: radiating peristomatal striae in irregular orientation from ledge cells. Stomatal size: L $(41.38-52.38 \mu \mathrm{m}) \times \mathrm{W}(22.79-31.21 \mu \mathrm{m})$. Trichome distribution: present on dorsal sepal, synsepal, lateral petals and labellum. Two major groups of trichomes were observed on the dorsal sepal; non-glandular and glandular trichomes. The long and non-glandular trichomes were mostly located marginally and glandular trichomes on the dorsal sepal. Trichome type: non-glandularType I, II, III, and V. Pustular glands: sessile, widely-scattered on sepals. Papillae: congregated on labellum, globular, striated and connected by radiating striae.

Paphiopedilum niveum (Fig. 3). Waxes: scattered, warty-granulated and flake-like. Epicuticular ornamentation: Type II, III, V and VI. Stomata formation: paraficial, semi-raised from the epidermal wall. Stomata distribution: sparsely occurred on dorsal sepals and synsepal. Stomata ornamentation: narrowly elliptical outer ledges and distinct irregular quadrilateral guard cells. Contact cells indistinguishable from the neighbouring stomatal apparatus. Stomatal cuticular striation: long radiating buttressed striae. Stomatal size: L $(37.98-45.45 \mu \mathrm{m}) \times$ W (30.32-38.66 $\mu \mathrm{m})$. Trichome distribution: presence on dorsal sepal, synsepal, lateral sepals, labellum and staminode. Non-glandular trichomes were dense in petals and sepals. Glandular trichomes occasionally occur on the labellum. Trichome type: non-glandular-Type I, II, III, IV, and V; glandular-Type VI. Pustular glands: occur sparsely on sepals, sessile to 
subsessile, resemble subsessile trichomes, except the former commonly striated or connected by striae, or resemble papillae, except the former not prominently protruding. Papillae: congregated on labellum, tall striated.

Comparative study on the floral-surface micromorphology.- Prominent cuticular sculpturing was clearly observed on the epidermal surface of the selected species and varied significantly in anticlinal and periclinal wall characteristics. Stomata were present in floral parts of $P$. barbatum but only occurred occasionally for $P$. callosum var. sublaeve and $P$. niveum. Trichomes were observed in all studied species. All had diverse types of trichomes on their floral parts. The features and occurrence of each micromorphology are shown in Table 4 and 5.

Discussion. Questions have arisen over the usefulness of floral-surface micromorphology in the recircumscription of confusable Paphiopedilum species found in Peninsular Malaysia, P. barbatum and $P$. callosum var. sublaeve. At first, we discuss the taxonomic significance and then the physioecological importance of epicuticular ornamentation, stomata and trichomes. Non-glandular trichomes are classified as non-glandular for not functioned as secretory structures (Peterson \& Vermeer 1984). The nonglandular trichomes occur on various floral parts (Ko et al. 2007, Baran et al. 2010). Glandular trichomes, papillae and floral stomata play essential roles in fragrance and metabolite release which offers food to ensure pollinators revisit (Davies \& Turner 2004, Choi \& Kim 2013, Stpiczyñska et al. 2018).

Taxonomic aspects. - The invariable presence of warty-granulated and flake-like epicuticular waxes without any unique types on each floral part suggests no significance systematics value for the studied species. Contrariwise, the multi-pattern epicuticular ornamentation on the floral parts offers a significant taxonomic value to discriminate the infrasubgeneric P. barbatum and P. callosum var. sublaeve. The epicuticular sculptures are also consistent to differentiate them from their congener $P$. niveum (Table 4).

Stomata were found in all three studied
TABLE 5. Features and distribution of floral-surface micromorphology characteristics of Paphiopedilum barbatum, $P$. callosum var. sublaeve and $P$. niveum (trichome).

\begin{tabular}{|c|c|c|c|c|}
\hline Species & $\begin{array}{l}\text { Floral } \\
\text { Parts }\end{array}$ & $\begin{array}{c}\text { Trichome } \\
\text { type }\end{array}$ & $\begin{array}{l}\text { Glandular } \\
\text { trichomes }\end{array}$ & Papillae \\
\hline \multirow{5}{*}{ P. barbatum } & $\begin{array}{l}\text { Dorsal } \\
\text { Sepal }\end{array}$ & III & Absent & Absent \\
\hline & Synsepal & III & Absent & Absent \\
\hline & $\begin{array}{l}\text { Lateral } \\
\text { Petals }\end{array}$ & II, III & Absent & Absent \\
\hline & Labellum & II, III, V & Absent & Absent \\
\hline & Staminode & I, II, III & Absent & Absent \\
\hline \multirow{5}{*}{$\begin{array}{l}\text { P. callosum } \\
\text { var. } \\
\text { sublaeve }\end{array}$} & $\begin{array}{l}\text { Dorsal } \\
\text { Sepal }\end{array}$ & I, III, V, VI & Absent & Absent \\
\hline & Synsepal & I, II, III, V & Absent & Absent \\
\hline & $\begin{array}{l}\text { Lateral } \\
\text { Petals }\end{array}$ & II, V & Absent & Absent \\
\hline & Labellum & I, III, V & Absent & Present \\
\hline & Staminode & V & Absent & Absent \\
\hline \multirow{5}{*}{$P$. niveum } & $\begin{array}{l}\text { Dorsal } \\
\text { Sepal }\end{array}$ & I, IV, V & Absent & Absent \\
\hline & Synsepal & I, IV, V & Absent & Absent \\
\hline & $\begin{array}{l}\text { Lateral } \\
\text { Petals }\end{array}$ & II & Absent & Absent \\
\hline & Labellum & II, III, V, VI & Present & Present \\
\hline & Staminode & V & Absent & Absent \\
\hline
\end{tabular}

Paphiopedilum species. The contact cells obscurity could be a characteristic of a genus. Nevertheless, the stomata can be clearly distinguished based on the prominence of the guard cells and their shape. Solereder (1908) and Carpenter (2005) strongly emphasized the diagnostic importance of the morphology of the guard cells and their cuticular ledges. The outline of the pair of guard cells as seen in surface view is usually constant in the examined specimens and is also possible a characteristic of a genus. Also, stomata in P. barbatum differs significantly from $P$. callosum var. sublaeve and $P$. niveum by having clear and noticeably contact cells, epidermal cells and peristomatal rim but rather obscure guard cells. Here, we can also deliberately compare between P. barbatum and P. callosum var. sublaeve based on the stomata and stomatal formation when observed from the top view. In comparison, stomata in P. callosum var. sublaeve were superficial and standout distinctly with prominently raised guard cells. P. niveum had stomata slightly raised and irregular-shaped guard 
cells that may provide a unique diagnostic character at the species level. Based on the general designation of the stomatal size provided in Wilkinson (1979), the stomata present on the slipper orchids are termed as 'large', similar to Corybas holtumii and Corybas selangorensis (see Besi et al. 2019).

Dominance of simple non-glandular trichomes and occurrence of variegated stomata on the floral surface of the Paphiopedilum species may separate genus Paphiopedilum from other genera within the Cypripedioideae subfamily. In many cases, such trichomes were living cells whereas in others they were dead, and the protoplasm was replaced by air spaces (Fahn 1988) and easily distorted or torn as observed on the labellum of $P$. callosum var. sublaeve. Different types of trichomes possess varies morphological characteristics were distinctively occurred on these floral surfaces of Paphiopedilum species (Table 5). The simple non-glandular trichomes were dominant on the floral surface. In contrast, the papillae were scarce, localized and only occurred on the labellum of $P$. callosum var. sublaeve (globular and striated) and $P$. niveum (tall and striated). This suggests the presence of papillae with varied morphology on the labellum of Paphiopedilum are of systematic significance and can be used as a diagnostic character to distinguish them further morphologically. There were pustular glands observed on the sepals and petals that resemble either subsessile trichomes or papillae. Short and rugose nonglandular trichomes were formed by two to five cell tiers. The trichomes occurred at different length ranged from $61.11 \mu \mathrm{m}$ to $1533.3 \mu \mathrm{m}$ for P. barbatum, $48 \mu \mathrm{m}$ to $190 \mu \mathrm{m}$ for $P$. callosum var. sublaeve and $100 \mu \mathrm{m}$ to $240 \mu \mathrm{m}$ for $P$. niveum.

The presence of different types of simple nonglandular trichomes on the floral parts of the studied Paphiopedilum species denotes species specificity. It provides a piece of useful evidence for delineation of the confusable $P$. barbatum and $P$. callosum var. sublaeve. Morphologically, $P$. barbatum differs only by having dorsal sepal broadly ovate, petals with warts on upper or both margins and sometimes on the petals blades too, whereas $P$. callosum var. sublaeve has dorsal sepal broadly ovate to suborbicular and petals with warts on upper margin only (Seidenfaden \& Wood 1992, Leong 2014). Clearly, these diagnostic characters are inconspicuous without a definite boundary to discriminate and sometimes misleading. Therefore, here, floral-surface micromorphology serves as a steadfast advanced technique for the taxonomic circumscription of the confusable $P$. barbatum and $P$. callosum var. sublaeve. Micromorphologically, $P$. barbatum varies in the diversity of non-glandular trichomes on its floral parts compared to its complex, P. callosum var. laeve (Table 5). Conspicuously, the former species has the longest Type III non-glandular trichomes (1233.3-1533.3 $\mu \mathrm{m})$ on the margin of its lateral petals, noticeably elongated and moniliform with topmost cell very narrow, which such trichomes were absent in the latter species. Also, glandular trichomes occurred in $P$. callosum var. sublaeve but lacking in P. barbatum. Variability of the micromorphology observed on the staminode is systematically insignificant at infrasubgeneric level. Notwithstanding, a combination of the micromorphological characteristics on staminode separates $P$. barbatum and $P$. callosum var. sublaeve in subgenus Paphiopedilum.

The existence of certain trichome types allows differentiation of the Paphiopedilum species from different subgenera. Unlike $P$. barbatum and $P$. callosum var. sublaeve, $P$. niveum contrasts by having dense hairs (Type I non-glandular trichomes) along the margin of the staminode (Fig. 4). Besides having distinctive diversity of non-glandular trichomes, the confined distribution of different types of papillae found only on the labellum for $P$. callosum var. sublaeve and $P$. niveum are also distinguishing. The trichomes' length and papillae' diameters were not much diverse between the studied species.

Overall, the present research suggests floralsurface features to be very useful in delimitation of the infrageneric taxa from different subgenera of the genus by epicuticular ornamentation, stomata and trichomes. The data from this study laid evidence for delimiting two confusable Paphiopedilum species. It provides conclusive proof to support the molecular phylogenetic analyses and validates the possibility of natural hybridization occurrence in between $P$. barbatum and P. callosum var. sublaeve. Moreover, it demonstrates that the former is indeed distinct from the latter. The floral-surface characteristics differentiate species from two different subgenera to some extent based on the presence of different types 


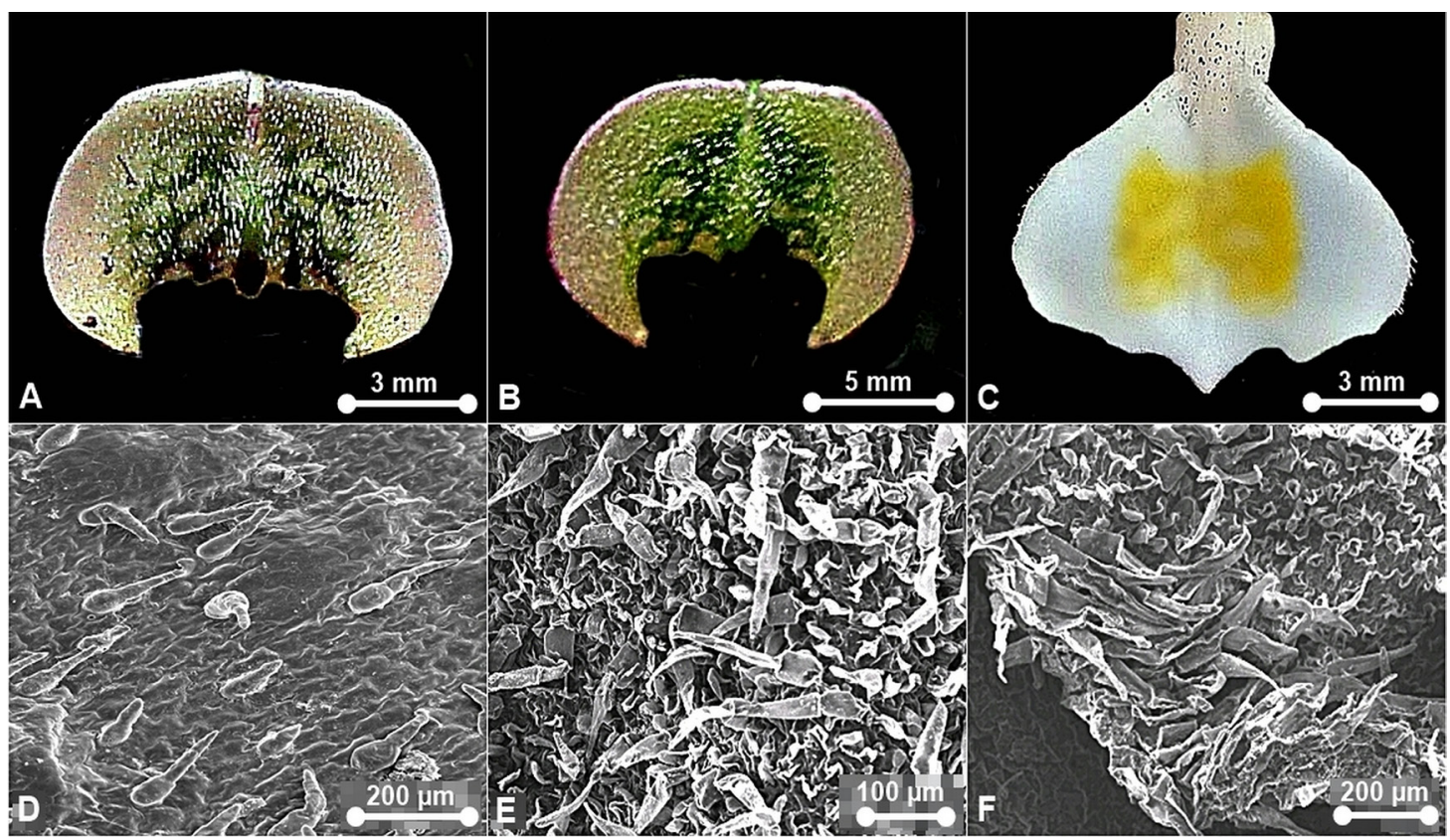

Figure 4. Staminode of Paphiopedilum and the epicuticular surface. A, D. Paphiopedilum barbatum. B, E. Paphiopedilum callosum var. sublaeve. C, F. Paphiopedilum niveum. Photographs by Edward Entalai Besi and Lam Shun Jia.

of epicuticular ornamentation and papillae on the labellum, and the diverse variation and distribution of the non-glandular trichomes on sepals and petals. Also, the occurrence of different formation, cuticular striation and ornamentation of stomata is of taxonomic interest in this study and can be used to identify the species.

Physioecological aspects. - The presence of dense epicuticular waxes on the floral surface of the selected Peninsular Malaysian Paphiopedilum species raises questions. One clear role of waxes is to protect the plant from desiccation and herbivorous insects (Davies $\&$ Turner 2004). It may or may not offer food rewards. In Maxillaria, one of the important ways insect attraction is achieved involves the secretion of waxlike material rich in lipids and protein (van der Pijl \& Dodson 1966, Davies et al. 2003). It is also reported that wasps may also collect wax from the labella of Maxillaria (Dressler 1993). Dense waxes on the labellum of $P$. callosum var. sublaeve and $P$. niveum may attract potential pollinators. Male Bactrocera fruit flies are often observed to probe the labellum, sepals and petals of Bulbophyllum species. The probing and licking behaviours displayed by the flies suggests that the pollinators' reward may be compounds released by the flower (Ong et al. 2011).

Orchid floral stomata are non-functional and practically closed in orchid flowers (Hew et al. 1980). Our finding supports this claim as the stomata found in the studied species were closed (Fig. 2K,L and Fig. 3F), or opened with a small aperture (Fig. 3E,G). Also, there were nectarostomata without a presence of guard cells (Fig. 2M), which might indicate modified stomata, cavities where the waxes are exuded through on the cuticular surface, known to occur and are of great diagnostic value in some plant species (Pant \& Mehra 1965, Wilkinson 1979, Chattopadhyay et al. 2014, Prashanta Kumar \& Krishnaswamy 2014, Baruah 2017, Verma et al. 2018, Besi et al. 2019, Besi et al. 2020). Notably, apertures formed by the detachment of the trichomes which could have been mistakenly identified as stomata in plant specimens (Fig. 2I,J). Waxes observed on floral surface indicates an active function of the unspecialized osmophores on the floral parts of orchid species, the regular epidermal cells secreting volatile oils (Toh et al. 2017). Identical to our previous finding on Corybas anatomical profiling work, the trichomes and stomata of the Paphiopedilum species offer more values on anatomical adaptions 
in defence and pollination rather than for the release of fragrance (Besi et al. 2019). The densely hairy staminode may mimic an aphid mimicry as aphidophagous hoverflies lay eggs on false brood sites on their flowers (Bänziger et al. 2012, Jin et al. 2014). Paphiopedilum flowers are postulated rewardless or nectarless to the pollinators and luring hoverflies or bees by deceit (Bänziger 1996, 2011, Bänziger et al. 2012). This is supported by the lack of glandular trichomes, papillae and stomata occurring on the labellum and reproductive parts. However, thorough observations are lacking for Malaysian species (Leong 2014). The low occurrence of glandular trichomes, papillae and stomata on the floral parts explains the unscented flowers of $P$. barbatum and $P$. callosum var. sublaeve. Except, the labellum of $P$. callosum var. sublaeve and $P$. niveum, although lacking trichomes, are heavily clothed with papillae. Though no odour is detectable to the human nose in $P$. niveum, when a live flower is wrapped in a plastic bag for a couple of hours, $P$. niveum release a faint, pleasant fragrance (Bänziger et al. 2012). Therefore, the papillae may function as osmophores for $P$. niveum.

Conclusions. Features of floral parts surfaces, such as epicuticular ornamentation, stomata (formation, distribution, ornamentation and size), trichome (distribution and type) are recognized as useful to differentiate highly confusable species and delimit species from different subgenera of Paphiopedilum. SEM analysis of floral-surface micromorphology supports a segregation of a narrowly distributed $P$. callosum var. sublaeve from $P$. barbatum, a widespread species in Peninsular Malaysia. The latter species is known to produce a wide range of flower morphology and colouration along the elevation gradients. All these diagnostic characters based on floral-surface morphology of these selected species should be used with care at intergeneric and intersubgeneric levels. It should be noted that these characters are far from being enough at this time to fully discriminate Paphiopedilum species in Peninsular Malaysia. A larger sampling is required to know the level of variation of the analyzed characters and to be able to make stronger conclusions. The usefulness of these floral microcharacters in biological and ecological aspects is difficult to predict based on the current preliminary finding. A further investigation on chemical compound released by Paphiopedilum flowers in relation to pollination mechanism is highly recommended.

Acknowledgements. We are grateful to the Forest Department Peninsular Malaysia for granting us the permit to access the studied areas. We would like to thank the UPM-KRIBB (Korea Research Institute of Bioscience and Biotechnology) Vot. 6384300 and UPM for the research funding (Putra Grant No. 9413603). Also, special gratitude to UPM and the Ministry of Higher Education Malaysia (MOHE) for sponsoring this Doctorate Degree undertaking. We thank the staffs and friends who directly or indirectly contributed to the success of this study, especially $\mathrm{Ng}$ Yong Jin, Tan Mui Ching, Michael Charles Rajaram, Dr. Kenny Khor and Dr. Farah Alia Nordin [Plant Taxonomist, Universiti Sains Malaysia (USM), Malaysia]. A special thanks to Dr. Mohd. Norfaizal Ghazalli [Plant Taxonomist, Malaysian Agricultural Research and Development Institute (MARDI), Malaysia] for his helpful comments on the manuscript and Prof. S.G. Tan for reviewing the manuscript and editing the English. The authors contributed equally to this paper and approved the paper for release and agree with its contents.

\section{LITERATURE CITED}

Adedeji, O., Ajuwon, O. Y. \& Babawale, O. O. (2007). Foliar epidermal studies, organographic distribution and taxonomic importance of trichomes in the family Solanaceae. International Journal of Botany, 3(3), 276-282.

Angulo, M. B. \& Dematteis, M. (2014). Floral microcharacters in Lessingianthus (Vernonieae, Asteraceae) and their taxonomic implications. Plant Systematics and Evolution, 300(8), 1925-1940.

Atwood, J. (1984). The Relationships of the Slipper Orchids (Subfamily Cypripedioideae). Selbyana, 7, 129-247.

Averyanov, L. V., Phan, K. L. \& Nguyen, T. H. (2007). Natural intraspecific hybridization in the genus Paphiopedilum (Orchidaceae: Cypripedioideae) in Vietnam. Orchids; the Magazine of the American Orchid Society, 76, 209-219.

Bänziger, H. (1996). The mesmerizing wart: the pollination strategy of epiphytic lady slipper orchid Paphiopedilum villosum (Lindl.) Stein (Orchidaceae). Botanical Journal of the Linnean Society, 121(1), 59-90.

Bänziger, H. (2011). Pollination mechanisms in Paphiopedilum species. Renziana, 1, 42-43.

Bänziger, H., Pumikong, S. \& Srimuang, K. (2012). The missing link: bee pollination in wild lady slipper orchids 
Paphiopedilum thaianum and P. niveum (Orchidaceae) in Thailand. Mitteilungen der Schweizerischen Entomologischen Gesellschaft, 85, 1-26.

Baran, P., Ozdemir, C. \& Aktas, K. (2010). Structural investigation of the glandular trichomes of Salvia argentea. Biologia, $65,33-38$.

Baruah, A. (2017). Peduncle, pedicel, and capsule epidermal characters of certain orchid species from North East India. The Journal of The Orchid Society of India, 31, 65-69.

Besi, E. E., Lai, Y. E., Khor, H. E., Tan, M. C., Nulit, R. \& Go, R. (2019). Floral-Surface Micromorphology of Corybas selangorensis J.Dransf. \& G.Sm. and Corybas holttumii J.Dransf. \& G.Sm. (Orchidaceae). The Journal of The Orchid Society of India, 33, 47-56.

Besi, E. E., Nikong, D., Mustafa, M., Yong, C. S. Y. \& Go, R. (2020). Taxonomic placement of four confusable Crepidium species (Orchidaceae, Malaxidinae) based on macro-and micro-morphological analyses, including a note on two new records to Peninsular Malaysia. Phytotaxa, 454(1), 31-44.

Braem, G. J. (1988). Paphiopedilum: a monograph of all tropical and subtropical Asiatic slipper orchids. Schmersow: Brucke-Verl. 249 p.

Bridson, D. \& Forman, L. (2000). The herbarium handbook. 3rd Edition. Kew: Royal Botanic Gardens. 348 p.

Burns-Balogh, P. \& Hesse, M. (1988). Pollen morphology of the cypripedioid orchids. Plant Systematics and Evolution, 158(2-4), 165-182.

Carpenter, K. J. (2005). Stomatal architecture and evolution in basal angiosperms. American Journal of Botany, 92(10), $1595-1615$.

Cash, C. (1991). The slipper orchids. Portland, Oregon: Timber Press. 228 p.

Chattopadhyay, A., Pathak, P. \& Mahant, K. C. (2014). Foliar features in some Indian Orchids: Subtribe Habenariinae (Orchideae, Orchidoideae). The Journal of The Orchid Society of India, 28, 47-59.

Cheadle, V. I. (1942). The occurrence and types of vessels in the various organs of the plant in the Monocotyledoneae. American Journal of Botany, 29(6), 441-450.

Chen, X. C., Zhu, G. H., Ji, Z. H., Lang, K. Y., Luo, Y. B. \& Cribb, P. (2005). Orchidaceae. In: Z. Y. Wu \& P. H. Raven (Eds), Flora of China. Vol. 25 (pp. 19-72). St. Louis: Science Press, Beijing and Missouri Botanical Garden.

Chochai, A., Leitch, I. J., Ingrouille, M. J. \& Fay, M. F. (2012). Molecular phylogenetics of Paphiopedilum (Cypripedioideae; Orchidaceae) based on nuclear ribosomal ITS and plastid sequences. Botanical Journal of the Linnean Society, 170, 176-196.

Choi, J. S. \& Kim, E. S. (2013). Structural features of glandular and non-glandular trichomes in three species of Mentha. Applied Microscopy, 43(2), 47-53.

Cribb, P. J. (1998). The genus Paphiopedilum. 2nd Edition. Kota Kinabalu: Natural History Publications. 427 p.

Davies, K. L. \& Turner, M. P. (2004). Morphology of floral papillae in Maxillaria Ruiz \& Pav. (Orchidaceae). Annals of Botany, 93(1), 75-86.

Davies, K. L., Turner, M. P. \& Gregg, A. (2003). Lipoidal labellar secretions in Maxillaria Ruiz \& Pav. (Orchidaceae). Annals of Botany, 91, 439-446.

Dressler, R. L. (1993). Phylogeny and classification of the orchid family. Massachusetts: Cambridge University Press. 314 p.

Duncan, R. E. \& Macleod, R. A. (1949). The chromosomes of the continental species of Paphiopedilum with solid green leaves. American Orchid Society Bulletin, 18, 84-89.

Fahn, A. (1988). Secretory tissues in vascular plants. New Phytologist, 108(3), 229-257.

Ghazalli, M. N., Tamizi, A. A., Esa, M. I. M., Besi, E. E., Nikong, D., Nordin, A. R. M. \& Zaini, A. Z. (2019). The systematic significance of leaf epidermal micro-morphology of ten Nepenthes species (Nepenthaceae) from Peninsular Malaysia. Reinwardtia, 18(2), 81-96.

Ghimire, B., Jeong, M. J., Suh, G. U., Heo, K. \& Lee, C. H. (2018). Seed morphology and seed coat anatomy of Fraxinus, Ligustrum and Syringa (Oleeae: Oleaceae) and its systematic implications. Nordic Journal of Botany, $36(10)$, e01866.

Govaerts, R., Bernet, P., Kratochvil, K., Gerlach, G., Carr, G., Alrich, P., Pridgeon, A. M., Pfahl, J., Campacci, M. A., Baptista, D. H., Tigges, H., Shaw, J., Cribb, P., George, A., Kreuz, K. \& Wood, J. J. (2021). World Checklist of Orchidaceae. Kew: The Board of Trustees of the Royal Botanic Gardens. Available from http://apps.kew.org/wcsp/ [Accessed on 9 April 2021].

Guan, Z. J., Zhang, S. B., Guan, K. Y., Li, S. Y. \& Hu, H. (2011). Leaf anatomical structures of Paphiopedilum and Cypripedium and their adaptive significance. Journal of Plant Research, 124(2), 289-298.

Hew, C. S., Lee, G. L. \& Wong, S. C. (1980). Occurrence of non-functional stomata in the flowers of tropical orchids. Annals of Botany, 46(2), 195-201. 
Holm, T. (1904). The root-structure of North American terrestrial Orchideae. American Journal of Science, 168, $197-212$. Jin, X. H., Ren, Z. X., Xu, S. Z., Wang, H., Li, D. Z. \& Li, Z. Y. (2014). The evolution of floral deception in Epipactis veratrifolia (Orchidaceae): from indirect defense to pollination. BMC Plant Biology, 14(1), 63.

Karasawa, K. (1979). Karyomorphological studies in Paphiopedilum, Orchidaceae. Bulletin of the Hiroshima Botanical Garden, 2, 1-149.

Karasawa, K. \& Aoyama, M. (1988). Karyomorphological studies on two species of Paphiopedilum. Bulletin of the Hiroshima Botanical Garden, 10, 1-6.

Ko, K. N., Lee, K. W., Lee S. E. \& Kim, E. S. (2007). Development and ultrastructure of glandular trichomes in Pelargonium $\times$ fragrans 'mabel grey'(Geraniaceae). Journal of Plant Biology, 50(3), 362-368.

Kong, M. J. \& Hong, S. P. (2018). The taxonomic consideration of floral morphology in the Persicaria sect. Cephalophilon (Polygonaceae). Korean Journal of Plant Taxonomy, 48(3), 185-194.

Leong, P. K. F. (2014). Flora of Peninsular Malaysia - Cypripedioideae. Malesian Orchid Journal, 13, $113-127$.

McGough, H. N., Roberts, D. L., Brody, C. \& Kowalczyk, J. (2006). An introduction to slipper orchids covered by the Convention of International Trade in Endangered Species. Kew: Royal Botanical Gardens. Available at http://kew.org/ conservation/CITES [Accessed on November 3, 2019].

Newton, G. D. \& Williams, N. H. (1978). Pollen morphology of the Cypripedioideae and the Apostasioideae (Orchidaceae). Selbyana, 2(2/3), 169-182.

Ong, P. T., Hee, A. K. W., Wee, S. L. \& Tan, K. H. (2011). The attraction of flowers of Bulbophyllum (Section Sestochilus) to Bactrocera fruit flies (Diptera: Tephritidae). Malesian Orchid Journal, 8, 93-102.

Pant, D. D. \& Mehra, B. (1965). Ontogeny of stomata in some Rubiaceae. Phytomorphology: An International Journal of Plant Morphology, 15(3), 300-310.

Peterson, R. L. \& Vermeer, J. (1984). Histochemistry of trichomes. In: E. Rodriguez, P. L. Healey \& J. Mehta (Eds.), Biology and chemistry of plant trichomes (pp. 71-94). New York: Plenum Press.

Pfitzer, E. H. H. (1903). Orchidaceae-pleonandrae. In: A. Engler (Ed.), Das Pflanzenreich, 12(Iv. 50) (pp. 27-42). Leipzig : Verlag von Wilhelm Engelmann (Druck von Breitkopf \& Härtel in Leipzig).

Piwowarczyk, R. (2015). Seed micromorphology of central European Orobanche and Phelipanche (Orobanchaceae) in relation to preferred hosts and systematic implications. Australian Systematic Botany, 28(3), 124-136.

Prashanta Kumar, H. G. \& Krishnaswamy, K. (2014). Preliminary leaf epidermal studies in a few epiphytic orchids. The Journal of The Orchid Society of India, 28, 91-97.

Rajaram, M. C., Yong, C. S. Y., Gansau, J. A. \& Go, R. (2019). DNA barcoding of endangered Paphiopedilum species (Orchidaceae) of Peninsular Malaysia. Phytotaxa, 387(2), 94-104.

Rankou, H. (2015a). Paphiopedilum barbatum. The IUCN Red List of Threatened Species 2015, e.T43320121A43327794. Doi: http://dx.doi.org/10.2305/IUCN.UK.2015-2.RLTS.T43320121A43327794.en

Rankou, H. (2015b). Paphiopedilum niveum. The IUCN Red List of Threatened Species 2015, e.T43321552A43327924. http://dx.doi.org/10.2305/IUCN.UK.2015-2.RLTS.T43321552A43327924.en

Rankou, H. (2015c). Paphiopedilum rothschildianum. The IUCN Red List of Threatened Species 2015, e.T43322055A43327969. http://dx.doi.org/10.2305/IUCN.UK.2015-2.RLTS.T43322055A43327969.en

Rankou, H. (2015d). Paphiopedilum sanderianum. The IUCN Red List of Threatened Species 2015, e.T43322127A43327974. http://dx.doi.org/10.2305/IUCN.UK.2015-2.RLTS.T43322127A43327974.en

Rankou, H. \& O’Sullivan, R. (2015). Paphiopedilum stonei. The IUCN Red List of Threatened Species 2015, e.T43322204A43327989. http://dx.doi.org/10.2305/IUCN.UK.2015-2.RLTS.T43322204A43327989.en

Rankou, H., Averyanov, L. \& Svengsuksa, B. (2015). Paphiopedilum callosum. The IUCN Red List of Threatened Species 2015, e.T191704A1999308. http://dx.doi.org/10.2305/IUCN.UK.2015-2.RLTS.T191704A1999308.en

Rosso, S. W. (1966). The vegetative anatomy of the Cypripedioideae (Orchidaceae). Botanical Journal of the Linnaean Society, 59, 309-341.

Savvides, A., Fanourakis, D. \& van Ieperen, W. (2011). Co-ordination of hydraulic and stomatal conductance across light qualities in cucumber leaves. Journal of Experimental Botany, 63(3), 1135-1143.

Seidenfaden, G. \& Wood, J. J. (1992). The orchids of Peninsular Malaysia and Singapore. Kew: Royal Botanic Garden. 779 p.

Shope, J. C. \& Mott, K. A. (2006). Membrane trafficking and osmotically induced volume changes in guard cells. Journal of Experimental Botany, 57, 4123-4131.

Solereder, H. (1908). Systematic anatomy of the dicotyledons: a handbook for laboratories of pure and applied botany. (Translated by L. A. Boodle \& F. E. Fritsch. Revised by D. H. Scott) 2 vols. Oxford: Clarendon Press. pp. 645-1182. 
Stpiczyńska, M., Płachno, B. J. \& Davies, K. L. (2018). Nectar and oleiferous trichomes as floral attractants in Bulbophyllum saltatorium Lindl. (Orchidaceae). Protoplasma, 255(2), 565-574.

Theobald, W. L., Krauhulik, J. L. \& Rollins, R. C. (1979). Trichome description and classification. In: C. R. Metacalfe \& L. Chalk (Eds.), Anatomy of dicotyledons, Vol. 1, Second Edition (294 p). Oxford: Clarendon Press.

Toh, C., Mohd-Hairul, A. R., Ain, N. M., Namasivayam, P., Go, R., Abdullah, N. A. P., Abdullah, M. O. \& Abdullah, J. O. (2017). Floral micromorphology and transcriptome analyses of a fragrant Vandaceous Orchid, Vanda Mimi Palmer, for its fragrance production sites. BMC research notes, 10(1), 554.

Upchurch, G. R. (1984). Cuticle evolution in Early Cretaceous angiosperms from the Potomac Group of Virginia and Maryland. Annals of the Missouri Botanic Garden, 71, 522-550.

van der Ent, A., van Vugt, R. \& Wellinga, S. (2015). Ecology of Paphiopedilum rothschildianum at the type locality in Kinabalu Park (Sabah, Malaysia). Biodiversity and conservation, 24(7), 1641-1656.

van der Pijl, L. \& Dodson, C. H. (1966). Orchid flowers, their pollination and evolution. Coral Gables: University of Miami Press. $214 \mathrm{p}$.

Verma, J., Thakur, K., Kusum, Sembi, J. K. \& Pathak, P. (2018). Leaf micromorphology of some Habenaria Willd. sensu lato (orchidaceae) species from Western Himalaya. The Journal of The Orchid Society of India, 32, 103-112.

Wilkinson, H. P. (1979). The plant surface (mainly leaf). In: C. R. Metcalfe \& L. Chalk (Eds.), Anatomy of dicotyledons, Vol. 1, Second Edition (294 p). Oxford: Clarendon Press.

Williams, N. H. \& Broome, C. R. (1976). Scanning Electron Microscopy of orchid pollen. American Orchid Society Bulletin, August, 699-707. 
LANKESTERIANA 